\title{
Article 11. Transboundary Cooperation
}

1. In instances where the same genetic resources are found in situ within the territory of more than one Party, those Parties shall endeavor to cooperate, as appropriate, with the involvement of indigenous and local communities concerned, where applicable, with a view to implementing this Protocol.

2. Where the same traditional knowledge associated with genetic resources is shared by one or more indigenous and local communities in several Parties, those Parties shall endeavor to cooperate, as appropriate, with the involvement of the indigenous and local communities concerned, with a view to implementing the objective of this Protocol.

\section{Overview}

Article 11 identifies two instances in which transboundary cooperation is required, at least as a best-endeavor effort: when the same genetic resources are found in the territory of more than one country; and when the same traditional knowledge is shared by indigenous and local communities located in several Parties. This is an acknowledgment of the complexities that will be faced in implementing the mainly bilateral ABS approach embodied in the Nagoya Protocol, in particular in consideration of the fact that several genetic resources and traditional knowledge are shared among different Parties. One of the best-known ABs transactions, in fact, involved the San peoples' knowledge of the hunger-suppressant properties of hoodia, which was shared by San communities in South Africa, Namibia, Angola and Botswana. ${ }^{1}$

Although similarly worded, the two provisions contained in Article 11 are based on different legal concepts. Transboundary cooperation related to genetic resources is based on the notion of sovereign rights of States over genetic resources and establishes a duty to endeavor to cooperate in instances where the same genetic resources are found in situ under the jurisdiction of more than one Party. It also foresees a role for indigenous and local communities

1 Singh Nijar "An Asian Developing Country's View," op. cit., 261; and generally: Munyi and Jonas, "Implementing the Nagoya Protocol," op. cit.; and Wyndberg, Schroeder and Chennels, Indigenous Peoples, Consent and Benefit-sharing, op. cit.

(C) Elisa Morgera, Elsa Tsioumani, and Matthias Buck, 2015.

This is an open access chapter distributed under the terms of the Creative Commons Attribution-Noncommercial 3.0 Unported (CC-BY-NC 3.0) License. 
in case the genetic resources at stake are 'held' by these communities. ${ }^{2}$ Article 11(1) thus specifically concerns countries of origin of genetic resources. Transboundary cooperation related to traditional knowledge, on the other hand, reflects the obligation of States under international law to protect the rights of indigenous and local communities over their traditional knowledge, which extends to inter-State cooperation with the involvement of the communities concerned.

Both obligations aim to address the concern about a possible competition for benefits in the development and implementation of national ABs frameworks to attract potential users interested in obtaining access to the same genetic resource or the same traditional knowledge that are present in different Parties. ${ }^{3}$ The two obligations will be analyzed in turn below, after having commented on their common features in terms of the obligation to cooperate.

\section{Obligation to Cooperate}

The duty of international cooperation has never been defined internationally, but is understood as the obligation for States to enter into coordinated action under a legal regime so as to achieve its specific goal. ${ }^{4}$ As opposed to an obligation of solidarity, ${ }^{5}$ each State is expected to benefit from the cooperative relationship in a direct and concrete manner. ${ }^{6}$ In both cases addressed by Article 11, the obligation to cooperate is qualified: it requires States to 'endeavor to cooperate, as appropriate.' The Protocol, therefore, does not require Parties to reach agreement on joint PIC and MAT. ${ }^{7}$ It rather requires Parties to exert

2 Nagoya Protocol Articles 5(2) and 6(2). See this commentary on Articles 5, section 3, and 6, section 4 .

3 See proposal of operational text on benefit-sharing by Namibia on behalf of the African Group in СвD Working Group on ABs, "Collation of Operative Text submitted," UNEP/CBD/ WG-ABs /7/4, 15, paragraphs 5-6. Greiber et al., Explanatory Guide, op. cit., 133.

4 Rüdiger Wolfrum, "Cooperation, International Law of," in Wolfrum, Max Planck Encyclopedia, op. cit., paragraph 2; and particularly in the case of international environmental law, paragraphs 28-31.

5 Discussed in this commentary on Articles 22-25.

6 Danilo Campanelli, "Solidarity, Principle of," in Wolfrum, Max Planck Encyclopedia, op. cit., paragraph 12.

7 The Permanent Court of International Justice has stated that 'an obligation to negotiate does not imply an obligation to reach agreement': Permanent Court of International Justice, Railway Traffic between Lithuania and Poland, Advisory Opinion (15 October 1931), 116. We are grateful to James Harrison for a useful exchange of ideas on this matter. 
good-faith efforts to identify potentially concerned Parties and engage them with a view to reaching agreement on coordinated action. ${ }^{8}$ The choice of the means to identify and engage other concerned States is left to each Party ('as appropriate'). But lack of any reasonable effort to identify and engage potentially concerned States would be in violation of this due diligence obligation. If agreement cannot be reached, Article 11 does not impede States from making unilateral decisions, but it creates the expectation that such decisions will be made taking in consideration other States' and, where relevant, indigenous and local communities' interests, in realizing the objective of the Protocol. ${ }^{9}$ Article 11 may also entail the obligation for Parties to address persistent or recurring difficulties in implementing this provision by progressively developing the legal regime established by the Nagoya Protocol, ${ }^{10}$ through its governing body.11

Article 11 does not specify which types of measures Parties should consider in transboundary cooperation. The purpose of such measures is, however, 'implementing this Protocol,', 12 so transboundary cooperation arguably extends to access, benefit-sharing and compliance. ${ }^{13}$ This could include collaboration to document existing genetic resources within the jurisdiction of cooperating Parties; establish joint facilities for deciding on access requests; engage in

International Tribunal on the Law of the Sea (ITLOS), Southern Bluefin Tuna (New Zealand v. Japan; Australia v.Japan), Order (27 August 1999), 280, paragraph 90(1)(e).

9 See this commentary on Article 1.

$10 \quad$ Wolfrum, "Cooperation," op. cit., paragraph 28.

11 Nagoya Protocol Article 16(4)(a). See this commentary on Article 26, section 2.

12 It remains unclear why Article 11 seems to establish two slightly different aims for transboundary cooperation: in the case of cooperation over shared genetic resources, cooperation is aimed to implement the Protocol in its entirety, whereas in the case of shared traditional knowledge, cooperation is specifically targeting the objective of the Protocol (Article 1). In particular, the aim of the cooperation effort under Article 11(2) is not to implement the Protocol tout court, but only to implement its objective. Given the close relationship between Article 11(2) and the obligation of Parties under Articles 7 and 12, this seems illogical; not least, since traditional knowledge is not referred to in Article 1 of the Nagoya Protocol. The limiting reference to 'implementing the objective of this Protocol' rather than to 'implementing this Protocol' thus appears as a drafting oversight, that might be explained by the fact that Parties closed negotiations on Article 11(2) already in July 2010, when all the main substantive issues and related draft articles under negotiation, in particular those on traditional knowledge, were still unresolved. Compare draft article 8 in Cali Draft and in Montreal I draft.

13 Transboundary cooperation is in the latter sense a sub-set of the cooperation obligation in relation to alleged violations of domestic ABs frameworks under Article 15(3). See this commentary on Article 15, section 5. 
capacity building in neighboring Parties; establish common benefit-sharing mechanisms; and undertake joint compliance and enforcement initiatives. To provide an example, the 1996 Andean Community regime on genetic resources created a committee tasked with promoting management, monitoring, and control of access authorizations relating to genetic resources and their derivatives that exist in two or more member countries. ${ }^{14}$ The conclusion of bilateral and regional agreements can also be envisaged to implement Article $11,{ }^{15}$ and could result in the establishment of future specialized ABS agreements. ${ }^{16}$

As already discussed, ${ }^{17}$ the relationship between Article 11 and the 'transboundary situations' that may fall under a future multilateral benefit-sharing system under Article 10 is still to be clarified by Parties. So it may be expected that the interpretation of Article 11, and particularly the role of transboundary cooperation and its limitations vis-à-vis a possible multilateral benefit-sharing mechanism, will be clarified by the Protocol's governing body ${ }^{18}$ in the context of negotiations under Article 10. In that connection, it may be worth noting that Article 11 does not provide guidance as to benefit-sharing specifically, whereas Article 10 requires allocating benefits to conservation and sustainable use globally: this difference may contribute to create an incentive for Parties to exhaust all possible means for transboundary cooperation with a view to obtaining arising benefits. ${ }^{19}$

It can also be expected that certain institutions established at the international level under the Nagoya Protocol can support Parties in implementing Article 11. Information on the ABs Clearinghouse ${ }^{20}$ and instances of alleged non-compliance arising in the context of the Protocol's compliance procedures and mechanisms ${ }^{21}$ may facilitate the identification of situations requiring transboundary cooperation.

14 Andean Community, Common Regime on Access to Genetic Resources (Decision 391, 2 July 1996, in force 17 July 1996), Article 51; cited in Greiber et al., Explanatory Guide, op. cit., 134.

15 Young, "An International Cooperation Perspective," op. cit., 496.

16 See this commentary on Article 4, section 3.

17 See this commentary on Article 10, section 3.

18 Nagoya Protocol Article 26(4)(a). See this commentary on Article 26, section 2.

19 Dedeurwaerdere et al., "Governing Global Scientific Research Commons," op. cit., 419.

20 See this commentary on Article 14, sections 3-4.

21 See this commentary on Article 30. 
Parties are obliged to make a best-endeavor effort to cooperate in the Protocol's implementation in instances where more than one Party is the country of origin of genetic resources. The provision is, however, silent on how to establish that such situations exist. It remains to be seen how a Party can determine that the 'same genetic resource' is at stake. When are two or more Parties to be considered countries of origin of the same genetic resource ${ }^{22}$ Does the gene sequence need to be identical? Or mainly identical? Or only identical as regards genes that have expressed themselves in the organism under consideration? It seems to be excluded that Article 11 would bind all Parties within the geographical range of the 'species' whose genetic resources are utilized. Rather, as the 'genetic resources' utilized in research and development are frequently not present in all populations within a species, Article 11(1) may apply only when the populations of a species in these territories share the specific genetic or biochemical characteristics utilized. ${ }^{23}$ It has been noted that, from a scientific perspective, only plant genetic resources can be found in more than one country, because they can be characterized by great genetic stability, whereas microbial strains within the same species are not the same, and animal genetic resources may present differences from one individual to another within the same breed. ${ }^{24}$ As these questions were not discussed during the negotiation of the Protocol, some clarification by the Protocol's governing body would seem essential for operationalizing Article 11.

One possible challenge for the effective implementation of Article 11(1) could be situations where one Party that is a country of origin requires PIC and MAT for access to certain genetic resources, whereas another Party having the same genetic resources in its territory operates a free-access regime. ${ }^{25}$ Parties operating a free-access regime might also be less interested in documenting their genetic resources in situ so as to identify situations within the scope of Article 11(1). It appears difficult for a Party allowing free access to cooperate with neighboring Parties harboring the same genetic resources so as not to undermine the effectiveness and integrity of the latter's access framework. A balance between the obligation to cooperate and the right of a Party to decide in favor of a free-access regime will have to be struck in practice.

\footnotetext{
22 Dedeurwaerdere et al., “Governing Global Scientific Research Commons," op. cit., 419.

23 Greiber et al., Explanatory Guide, op. cit., 134.

24 Dedeurwaerdere et al., "Governing Global Scientific Research Commons," op. cit., 419.

25 That could be the case if a Party waives its right to require PIC: see this commentary on Article 6, section 3.1.
} 
When genetic resources are held by indigenous and local communities ${ }^{26}$ ('where applicable'), transboundary collaboration must occur with the involvement of the communities concerned. In this respect, the obligation should be understood and implemented in conjunction with other relevant Protocol provisions on benefit-sharing and relevant procedural guarantees, read in the light of relevant international human rights standards. ${ }^{27}$ Challenges may arise, in this respect, when indigenous and local communities have rights over genetic resources in one/some, but not, all relevant States. Still, all concerned States will be expected to exert best-endeavor efforts to effectively involve these communities in transboundary cooperation.

\section{Transboundary Cooperation Concerning Traditional Knowledge}

Article 11(2) calls for transboundary cooperation in the case of transboundary situations related to traditional knowledge, with a view to ensuring the effective involvement of all relevant communities in taking decisions on PIC and мAT. The provision may apply where members of the same indigenous or local communities live in more than one Party and where different indigenous or local communities in several Parties share the same traditional knowledge. ${ }^{28}$ As opposed to Article 11(1), this provision does not include the term 'where applicable,' as the Protocol recognizes that access to traditional knowledge can only occur with community PIC, or approval and involvement. ${ }^{29}$ As recalled above, the provision should be read in conjunction with other relevant Protocol provisions on benefit-sharing and relevant procedural guarantees, including relevant international human rights standards. ${ }^{30}$

It is not self-evident what 'same' traditional knowledge means, however. It could point to traditional knowledge linked to the same biochemical composition or to similar properties or applications ${ }^{31}$ that is held by indigenous and local communities living across national boundaries. The determination of the

26 Nagoya Protocol Article 6(2). See this commentary on Article 6, section 4.

27 See Introduction to this commentary, section 4 and this commentary on Article 6, section 3, and Article 12.

28 On issues related to shared traditional knowledge, see Manuel Ruiz Muller, Protecting Shared Traditional Knowledge: Issues, Challenges and Options (Geneva: International Centre for Trade and Susatinable Development, 2013).

29 See this commentary on Article 7.

$30 \quad$ See fn. 27 above.

31 Greiber et al., Explanatory Guide, op. cit., 135. 
existence of a situation falling under the scope of Article 11(2) could be left to indigenous peoples and local communities as the holders of the knowledge in question, in accordance with their customary laws and procedures, ${ }^{32}$ and possibly through the development of community protocols. ${ }^{33}$ The role of Parties is therefore to facilitate communities' identification of such situations and their effective involvement in transboundary cooperation. Challenges may arise, however, if different Parties in the territories of which the concerned communities are located regulate differently ABs in relation to traditional knowledge. There may also arise practical difficulties if the relevant traditional knowledge is considered a secret by some of the concerned communities, but not by others. Once again, peer learning and development of international guidance by the Nagoya Protocol's governing body would be useful, ${ }^{34}$ particularly in the context of its consideration of model contractual clauses and voluntary instruments. 35

32 Nagoya Protocol Article 12(1). See this commentary on Article 12, section 2.

33 See this commentary on Article 12, section 2.1.

34 Nagoya Protocol Article 26(4)(a). See this commentary on Article 26, section 2.

35 See this commentary on Articles 19-20. 